\title{
First Assessment of $\mathrm{NO}_{x}$ Sources at a Regional Background Site in North China Using Isotopic Analysis Linked with Modeling
}

\author{
Zheng Zong, ${ }^{\dagger} \S$ Xiaoping Wang, ${ }^{\ddagger}$ Chongguo Tian, ${ }^{* \dagger} \odot$ Yingjun Chen, " Yunting Fang, ${ }^{*, \perp}$ Fan Zhang," \\ Cheng Li, Jianzhong Sun, Jun $\mathrm{Li}^{\dagger}{ }^{\ddagger}{ }^{\dagger}$ and Gan Zhang
}

${ }^{\dagger}$ Key Laboratory of Coastal Environmental Processes and Ecological Remediation, Yantai Institute of Coastal Zone Research, Chinese Academy of Sciences, Yantai, Shandong 264003, China

${ }^{\ddagger}$ State Key Laboratory of Organic Geochemistry, Guangzhou Institute of Geochemistry, Chinese Academy of Sciences, Guangzhou, Guangdong 510640, China

${ }^{\S}$ University of Chinese Academy of Sciences, Beijing, 100049, China

"Key Laboratory of Cities' Mitigation and Adaptation to Climate Change in Shanghai (CMA), College of Environmental Science and Engineering, Tongi University, Shanghai, 200092, China

${ }^{\perp}$ Key Laboratory of Forest Ecology and Management, Institute of Applied Ecology, Chinese Academy of Sciences, Shenyang, Liaoning 110164, China

${ }^{\#}$ College of Environmental Science and Engineering, South China University of Technology, Guangzhou, Guangdong 510006, China

Supporting Information

ABSTRACT: Nitrogen oxides $\left(\mathrm{NO}_{x}\right.$, including $\mathrm{NO}$ and $\left.\mathrm{NO}_{2}\right)$ play an important role in the formation of atmospheric particles. Thus, $\mathrm{NO}_{x}$ emission reduction is critical for improving air quality, especially in severely air-polluted regions (e.g., North China). In this study, the source of $\mathrm{NO}_{x}$ was investigated by the isotopic composition $\left(\delta^{15} \mathrm{~N}\right)$ of particulate nitrate $\left(\mathrm{p}-\mathrm{NO}_{3}{ }^{-}\right.$) at Beihuangcheng Island $(\mathrm{BH})$, a regional background site in North China. It was found that the $\delta^{15} \mathrm{~N}^{-N^{2}}{ }_{3}^{-}(n=120)$ values varied between $-1.7 \% 0$ and $+24.0 \% 0$ and the $\delta^{18} \mathrm{O}^{-} \mathrm{NO}_{3}{ }^{-}$values ranged from $49.4 \%$ to $103.9 \%$. On the basis of the Bayesian mixing model, $27.78 \pm 8.89 \%, 36.53 \pm 6.66 \%, 22.01 \pm 6.92 \%$, and $13.68 \pm 3.16 \%$ of annual $\mathrm{NO}_{x}$ could be attributed to biomass burning, coal combustion, mobile sources, and biogenic soil emissions, respectively. Seasonally, the four sources were similar in spring and fall. Biogenic soil emissions were augmented in summer in association with the hot and rainy weather. Coal combustion increased significantly in winter with other sources showing an obvious decline. This study confirmed that isotope-modeling by $\delta^{15} \mathrm{~N}^{-\mathrm{NO}_{3}}{ }^{-}$is a promising tool for partitioning $\mathrm{NO}_{x}$ sources and provides guidance to policymakers with regard to options for $\mathrm{NO}_{x}$ reduction in North China.
North China received worldwide attention in January 2013 due to a record-breaking haze pollution event (fine particle concentration $=995 \mu \mathrm{g} \mathrm{m}^{-3}$ ). Such pollution episodes are one of the greatest environmental issues in China. ${ }^{1}$ Fine particles $\left(\mathrm{PM}_{2.5}\right)$, the primary cause of haze pollution, can exert strong adverse effects on human health and visibility and directly or indirectly affect weather and climate. ${ }^{2,3}$ According to a recent study, 1.37 million premature mortalities in China can be ascribed to haze pollution. ${ }^{4}$ In response to the serious issue in North China, various studies have been conducted to investigate the mechanism of $\mathrm{PM}_{2.5}$ formation. Generally, $\mathrm{PM}_{2.5}$ can be directly emitted (primary) or formed through multiphase gas-toparticle conversion processes (secondary) in the atmosphere (Figure $\mathrm{S} 1$ ). ${ }^{5}$ Among these secondary processes, $\mathrm{NO}_{x}$ is believed to have a crucial function; for example, the aqueous oxidation of $\mathrm{SO}_{2}$ by $\mathrm{NO}_{2}$ is the key to efficient sulfate formation. ${ }^{6}$ In addition, $\mathrm{NO}_{x}$ is the precursor of $\mathrm{NO}_{3}{ }^{-}(\mathrm{R} 1-\mathrm{R} 8)$, which accelerates the

\section{INTRODUCTION}

transformation of $\mathrm{NH}_{3}$ into $\mathrm{NH}_{4}{ }^{+}$. Emissions of $\mathrm{NO}_{x}$ in China have increased gradually in recent decades. The control of these emissions has been incorporated into the "Twelfth Five-Year Plan for National Environment Protection (2011-2015)" of the Chinese government. Despite this, the annual growth rate of $\mathrm{NO}_{x}$ emissions in China reached 7.3\% between 1997 and $2006 .{ }^{7}$ Therefore, the need to reduce the emission of $\mathrm{NO}_{x}$ has increased in recent years, especially in the heavily polluted region of North China.

$$
\begin{aligned}
& \mathrm{NO}+\mathrm{O}_{3} \rightarrow \mathrm{NO}_{2}+\mathrm{O}_{2} \\
& \mathrm{NO}_{2}+\mathrm{hv} \rightarrow \mathrm{NO}+\mathrm{O}
\end{aligned}
$$

Received: December 21, 2016

Revised: $\quad$ May 14, 2017

Accepted: May 18, 2017

Published: May 18, 2017 


$$
\begin{aligned}
& \mathrm{O}+\mathrm{O}_{2} \rightarrow \mathrm{O}_{3} \\
& \mathrm{NO}_{2}+\cdot \mathrm{OH} \rightarrow \mathrm{HNO}_{3} \\
& \mathrm{NO}_{2}+\mathrm{O}_{3} \rightarrow \mathrm{NO}_{3}+\mathrm{O}_{2} \\
& \mathrm{NO}_{2}+\mathrm{NO}_{3} \rightarrow \mathrm{N}_{2} \mathrm{O}_{5} \\
& \mathrm{~N}_{2} \mathrm{O}_{5}+\mathrm{H}_{2} \mathrm{O} \rightarrow 2 \mathrm{HNO}_{3} \\
& \mathrm{HNO}_{3}+\text { Alkali } \rightarrow \mathrm{NO}_{3}^{-}
\end{aligned}
$$

To reduce emissions of $\mathrm{NO}_{x}$, it is crucial to know its sources, so that we can develop effective policies and abatement strategies. There are both natural and anthropogenic sources of $\mathrm{NO}_{x}$, and there is uncertainty over their relative contributions. The current source apportionment method of $\mathrm{NO}_{x}$ is based on air quality models, such as the Comprehensive Air Quality Model (CAMx) and Community Multiscale Air Quality (CMAQ). ${ }^{7,8}$ For example, $\mathrm{NO}_{x}$ over the Pearl River Delta region was apportioned by the CAMx model, and it was found that heavy-duty diesel vehicle and industrial point sources were the two major local $\mathrm{NO}_{x}$ sources. However, these models are usually accompanied by some level of uncertainty, resulting in source contributions that can differ in magnitude. A comparative study indicated that the outcome from the CAMx model was generally $10-20 \%$ higher than that of CMAQ for one specific data set in Japan. ${ }^{9}$ Alternatively, an analysis of the stable $\mathrm{N}$ isotopes within atmospheric-derived nitrate $\left(\delta^{15} \mathrm{~N}-\mathrm{NO}_{3}{ }^{-}\right)$may provide a powerful tool to apportion $\mathrm{NO}_{x}$ sources because $\mathrm{NO}_{x}$ is primarily oxidized to particulate nitrate $\left(\mathrm{p}-\mathrm{NO}_{3}{ }^{-}\right)$in the severely air-polluted regions (e.g., North China). Furthermore, the $\mathrm{N}$ isotopic signature of different anthropogenic and natural $\mathrm{NO}_{x}$ sources usually varies over a large range (Figure S2). Although the impact of kinetic and equilibrium isotopic fractionation of $\delta^{15} \mathrm{~N}$ during the conversion of $\mathrm{NO}_{x}$ to $\mathrm{NO}_{3}{ }^{-}$and the isotopic effect of $\delta^{15} \mathrm{~N}-\delta^{18} \mathrm{O}$ associated with $\mathrm{NO}_{x}$ oxidation must be considered, ${ }^{10}$ previous studies have suggested that $\delta^{15} \mathrm{~N}_{-} \mathrm{NO}_{3}{ }^{-}$ could be linked to $\mathrm{NO}_{x}$ sources. ${ }^{11,12}$ Relying on the change of $\delta^{15} \mathrm{~N}-\mathrm{NO}_{3}{ }^{-}$in ice cores, the source variation of $\mathrm{NO}_{x}$ from preindustrial times to the present day can be unambiguously reflected in samples from Greenland. ${ }^{13}$ However, it should be noted that isotope techniques only qualitatively reveal the source information, and methods that provide precise quantitative estimations need further exploration.

Stable isotope mixing models can be used to make precise estimations of the contribution of different sources to a mixture. ${ }^{14}$ A good example is the Bayesian model, which is commonly applied in the ecology field, such as predator-prey case studies. ${ }^{15}$ However, unlike its use in food-web analyses, which have settled model parameters, the application of the Bayesian model in the atmosphere is more difficult. In this study, we improved the Bayesian model for apportioning atmospheric $\mathrm{NO}_{x}$ sources and quantitatively apportioned the respective contribution of major sources for $\mathrm{NO}_{x}$ at a regional background site in North China. To the best of our knowledge, this is the first isotopic interpretation of $\mathrm{NO}_{x}$ in North China, and this modeling method could provide a new direction in the source apportionment of $\mathrm{NO}_{x}$. This has substantial implications for the development of efficient remediation policies to improve the air quality in the severely polluted region of North China.

\section{MATERIALS AND METHODS}

Sampling Site and Sample Collection. The sampling campaign was carried out from 20 August, 2014, to 15
September, 2015, at an environmental monitoring station of the State Ocean Administration of China on Beihuangcheng Island $(\mathrm{BH})\left(38^{\circ} 24^{\prime} \mathrm{N}, 120^{\circ} 55^{\prime} \mathrm{E}\right)$. This island is located at the demarcation line between the Bohai Sea and Yellow Sea, as shown in Figure S3. It is approximately $65 \mathrm{~km}$ north of Shandong Peninsula, $185 \mathrm{~km}$ east of the Beijing-Tianjin-Hebei (BTH) region, and $43 \mathrm{~km}$ south of Liaodong Peninsula. There is no industry on the island, and most islanders live by fishing. The average temperature, relative humidity $(\mathrm{RH})$, and wind speed (WS) were $13.45{ }^{\circ} \mathrm{C}, 66.23 \%$, and $4.22 \mathrm{~m} \mathrm{~s}^{-1}$, respectively, during the sampling period (Vantage Pro2, Davis, USA). Dominated by the Asian monsoon, air masses arriving at the island cover most of North China (Figure S4; Text S1), and the area has the ideal features of a regional background site.

During the sampling period, 120 fine particle $\left(\mathrm{PM}_{2.5}\right)$ samples were collected every 3 days on quartz fiber filters by a highvolume sampler (Tisch Environmental, Cleves, OH, USA) at a flow rate of $1.13 \mathrm{~m}^{3} \mathrm{~min}^{-1}$. The quartz fiber filters (QM-A, Whatman, Maidstone; UK: $20.3 \times 25.4 \mathrm{~cm}^{2}$ ) were heated for $6 \mathrm{~h}$ at $450{ }^{\circ} \mathrm{C}$ prior to use. The duration for each sample was $24 \mathrm{~h}$, starting at 6:00 a.m. (local time). Before and after sampling, the filters were processed following a $24 \mathrm{~h}$ equilibration at $25^{\circ} \mathrm{C}$ and $39 \% \mathrm{RH}$ and then weighed using an MC5 electronic microbalance (Sartorius, Göttingen, Germany), with $\pm 10 \mu \mathrm{g}$ sensitivity. Each filter was weighed three times, with the difference among the three repeats of weighing being less than $10 \mu \mathrm{g}$ for a blank filter and $20 \mu \mathrm{g}$ for a sampled filter. ${ }^{16}$

Isotopic and Chemical Analysis. The $\delta^{15} \mathrm{~N}$ and $\delta^{18} \mathrm{O}$ values of $\mathrm{NO}_{3}{ }^{-}$were quantified by an isotopic analysis of nitrous oxide $\left(\mathrm{N}_{2} \mathrm{O}\right) .{ }^{17}$ Briefly, $\mathrm{NO}_{3}{ }^{-}$from the filter extract was initially reduced to nitrite $\left(\mathrm{NO}_{2}^{-}\right)$by cadmium powder, and $\mathrm{NO}_{2}^{-}$was further reduced to $\mathrm{N}_{2} \mathrm{O}$ by sodium azide in an acetic acid buffer. Here, $\mathrm{NO}_{3}{ }^{-}$extract was diluted to about $15 \mu \mathrm{mol} \mathrm{L}{ }^{-1}$ in $5 \mathrm{~mL}$ with $0.5 \mathrm{M} \mathrm{NaCl}$. Then, $0.3 \mathrm{~g}$ of cadmium powder was added into the solution, and the $\mathrm{pH}$ was adjusted to about 9 by the addition of $0.1 \mathrm{~mL}$ of imidazole solution. The sample bottles were capped tightly with rubber septa, and samples were ultrasonically oscillated for $2 \mathrm{~h}$ at $40{ }^{\circ} \mathrm{C}$. The reduction rate of $\mathrm{NO}_{3}{ }^{-}$to $\mathrm{NO}_{2}{ }^{-}$was determined to be $98.33 \pm 6.65 \%(n=120)$. After standing for $12 \mathrm{~h}, 4 \mathrm{~mL}$ of solution was transferred to another sample bottle and sodium azide (1:1 of $20 \%$ acetic acid and sodium azide and purged with helium at $70 \mathrm{~mL} \mathrm{~min}^{-1}$ for $10 \mathrm{~min}$ ) was injected into it for the reaction $(30 \mathrm{~min})$, which was subsequently stopped by $0.4 \mathrm{~mL}$ of $10 \mathrm{M} \mathrm{NaOH}$. Finally, the $\delta^{15} \mathrm{~N}$ and $\delta^{18} \mathrm{O}$ of $\mathrm{N}_{2} \mathrm{O}$ were analyzed using an isotope ratio mass spectrometer (MAT253; Thermo Fisher Scientific, Waltham, MA, USA). In this study, the $\delta^{15} \mathrm{~N}$ and $\delta^{18} \mathrm{O}$ values were reported in parts per thousand relative to standards (international reference materials: $\mathrm{IAEA}-\mathrm{NO}_{3}{ }^{-}$, USGS32, USGS34, and USGS35): ${ }^{18}$

$$
\begin{aligned}
& \delta^{15} \mathrm{~N}=\left[\left({ }^{15} \mathrm{~N} /{ }^{14} \mathrm{~N}\right)_{\text {sample }} /\left({ }^{15} \mathrm{~N} /{ }^{14} \mathrm{~N}\right)_{\text {standard }}-1\right] \times 1000 \\
& \delta^{18} \mathrm{O}=\left[\left({ }^{18} \mathrm{O} /{ }^{16} \mathrm{O}\right)_{\text {sample }} /\left({ }^{18} \mathrm{O} /{ }^{16} \mathrm{O}\right)_{\text {standard }}-1\right] \times 1000
\end{aligned}
$$

The analytical precision determined from the replicates was less than $0.3 \%$ for $\delta^{15} \mathrm{~N}$ and $0.6 \%$ for $\delta^{18} \mathrm{O}$ for both standards and samples. In addition, $\mathrm{NO}_{2}{ }^{-}$concentrations in $\mathrm{BH}$ samples were lower than the detection limit and less than $2 \%$ of the $\mathrm{NO}_{3}{ }^{-}$; thus, they were neglected in the nitrogen and oxygen isotope analyses. ${ }^{19}$ Elemental carbon (EC) and major ionic species $\left(\mathrm{SO}_{4}{ }^{2-}, \mathrm{NH}_{4}^{+}, \mathrm{K}^{+}, \mathrm{Ca}^{2+}, \mathrm{Cl}^{-}, \mathrm{Na}^{+}, \mathrm{Mg}^{2+}\right.$, and $\left.\mathrm{NO}_{3}^{-}\right)$were 
measured following chemical methods (Text S2), which were described in detail previously. ${ }^{20}$

Bayesian Mixing Model. The Bayesian mixing model can use stable isotopes to determine the probability distribution of source contributions to a mixture, while explicitly accounting for the uncertainty associated with multiple sources, fractionation, and isotopic signatures. ${ }^{15}$ The model has been widely used in ecological studies, such as food-web analyses. ${ }^{21}$ In the Bayesian theorem, the contribution of each source is calculated on the basis of mixed data and prior information such that

$$
P\left(f_{\mathrm{q}} \text { Idata }\right)=\theta\left(\text { datal }_{\mathrm{q}}\right) \times p\left(f_{\mathrm{q}}\right) / \sum \theta\left(\text { datal }_{\mathrm{q}}\right) \times p\left(f_{\mathrm{q}}\right)
$$

where $\theta\left(\right.$ datal $\left.f_{\mathrm{q}}\right)$ and $p\left(f_{\mathrm{q}}\right)$ are the likelihood of the given mixed data and the prior probability of the given state of nature being true based on prior information, respectively. The denominator is a numerical approximation of the marginal probability of the data. In a Bayesian model (stable isotope mixing models using sampling-importance-resampling; MixSIR), isotope signatures from the mixed data are assumed to be normally distributed. Uncertainty in the distribution of isotope sources and their associated fractionation distribution are factored into the model by defining respective mean $(\mu)$ and standard deviation $(\sigma)$ parameters. Prior beliefs about proportional source contributions $\left(f_{\mathrm{q}}\right)$ are defined using the Dirichlet distribution, with an interval of $[0,1]$. To assess the likelihood of the given $f_{\mathrm{q}}$, the proposed proportional contribution is combined with a user-specified isotope distribution of sources and their associated fractionations to develop a proposed isotope distribution for the mixture. The posterior probability of proportional source contributions $\left(f_{\mathrm{q}}\right)$ is calculated by the Hilborn sampling-importance-resampling method. For the detailed model frame and computing method, readers should refer to Moore and Semmens. ${ }^{22}$

Generally, $\delta^{15} \mathrm{~N}_{-} \mathrm{NO}_{3}{ }^{-}$in the atmosphere is a complex function of the $\delta^{15} \mathrm{~N}$ of the emitted $\mathrm{NO}_{x}$, the equilibrium/ Leighton reaction fractionation factors, and the fractionation factor associated with the kinetic reaction $\left(\mathrm{NO}_{x} \rightarrow \mathrm{HNO}_{3}\right) .{ }^{23} \mathrm{On}$ the basis of an innovative study, ${ }^{10}$ a computation module evaluating the fractionation of the equilibrium/Leighton reaction was incorporated into MixSIR (Figure 1). The fractionation distribution was considered to be a hybrid of two dominant isotopic exchange reaction processes:

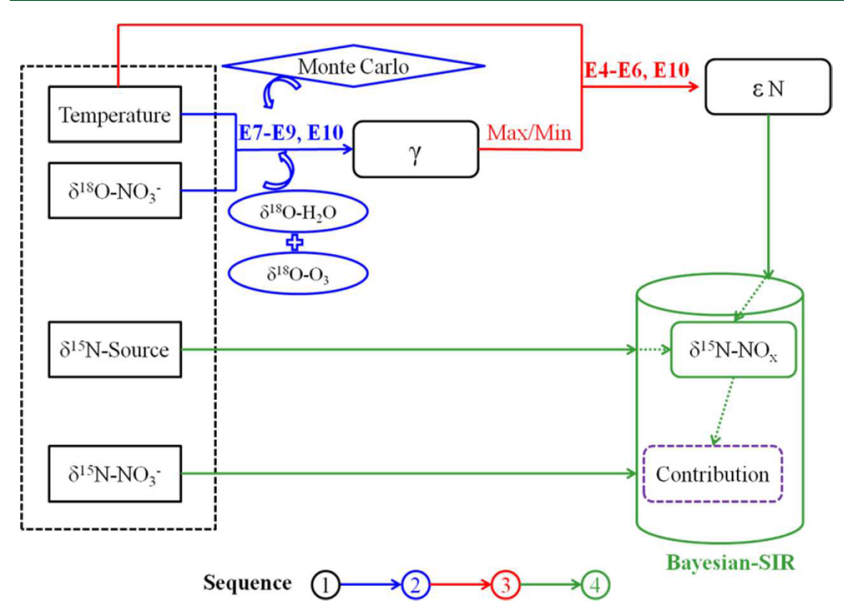

Figure 1. Principle and process of the improved Bayesian model in this study, the " $E$ " represents equation in the following section, " $\varepsilon \mathrm{N}$ " refers to $\mathrm{N}$ fractionation, and "SIR" is "sampling-importance-resampling".

$$
\begin{aligned}
\varepsilon \mathrm{N} & =\gamma \times \varepsilon\left(\delta^{15}{\mathrm{~N}-\mathrm{NO}_{3}}^{-}\right)_{\mathrm{OH}}+(1-\gamma) \\
& \times \varepsilon\left(\delta^{15} \mathrm{~N}^{-\mathrm{NO}_{3}}{ }^{-}\right)_{\mathrm{H}_{2} \mathrm{O}}=\gamma \times \varepsilon\left(\delta^{15} \mathrm{~N}-\mathrm{HNO}_{3}\right)_{\mathrm{OH}} \\
& +(1-\gamma) \times \varepsilon\left(\delta^{15} \mathrm{~N}-\mathrm{HNO}_{3}\right)_{\mathrm{H}_{2} \mathrm{O}}
\end{aligned}
$$

where $\gamma$ is the contribution ratio of the isotopic fractionation through the reaction of $\mathrm{NO}_{2}$ and photochemically produced . $\mathrm{OH}$, as shown by $\varepsilon\left(\delta^{15} \mathrm{~N}-\mathrm{NO}_{3}{ }^{-}\right)_{\mathrm{OH}}$. The remainder is produced by the hydrolysis of $\mathrm{N}_{2} \mathrm{O}_{5}$ on a wetted surface forming $\mathrm{HNO}_{3}$, named $\varepsilon\left(\delta^{15} \mathrm{~N}^{-\mathrm{NO}_{3}}{ }^{-}\right)_{\mathrm{H}_{2} \mathrm{O}}$. Assuming no kinetic isotope fractionation is associated with the reaction between $\mathrm{NO}_{2}$ and $\cdot \mathrm{OH}$, the $\varepsilon\left(\delta^{15} \mathrm{~N}-\mathrm{HNO}_{3}\right)$ can be calculated using a mass-balance:

$$
\begin{aligned}
& \varepsilon\left(\delta^{15} \mathrm{~N}-\mathrm{HNO}_{3}\right)_{\mathrm{OH}}=\varepsilon\left(\delta^{15} \mathrm{~N}-\mathrm{NO}_{2}\right)_{\mathrm{OH}} \\
& \quad=1000 \times\left[\frac{\left({ }^{15} \alpha_{\mathrm{NO}_{2} / \mathrm{NO}}-1\right)\left(1-f_{\mathrm{NO}_{2}}\right)}{\left(1-f_{\mathrm{NO}_{2}}\right)+\left({ }^{15} \alpha_{\mathrm{NO}_{2} / \mathrm{NO}} \times f_{\mathrm{NO}_{2}}\right)}\right]
\end{aligned}
$$

where ${ }^{15} \alpha_{\mathrm{NO}_{2} / \mathrm{NO}}$ is the equilibrium isotope fractionation factor between $\mathrm{NO}_{2}$ and $\mathrm{NO}$, which is a temperature-dependent function (see eq 10 and Table 1 ), and $f_{\mathrm{NO}_{2}}$ is the fraction of $\mathrm{NO}_{2}$ in the total $\mathrm{NO}_{x}$. The reported range of $\mathrm{fNO}_{2}$ is from 0.2 to $0.95 .^{23}$ Similarly, assuming a negligible kinetic isotope fraction with the equation $\left(\mathrm{N}_{2} \mathrm{O}_{5}+\mathrm{H}_{2} \mathrm{O}+\right.$ surface $\left.\rightarrow 2 \mathrm{HNO}_{3}\right)$, the $\varepsilon\left(\delta^{15} \mathrm{~N}-\mathrm{HNO}_{3}\right)_{\mathrm{H}_{2} \mathrm{O}}$ can be determined from the following equation:

$$
\begin{aligned}
& \varepsilon\left(\delta^{15} \mathrm{~N}-\mathrm{HNO}_{3}\right)_{\mathrm{H}_{2} \mathrm{O}}=\varepsilon\left(\delta^{15} \mathrm{~N}-\mathrm{N}_{2} \mathrm{O}_{5}\right)_{\mathrm{H}_{2} \mathrm{O}} \\
& \quad=1000 \times\left({ }^{15} \alpha_{\mathrm{N}_{2} \mathrm{O}_{5} / \mathrm{NO}_{2}}-1\right)
\end{aligned}
$$

where ${ }^{15} \alpha_{\mathrm{N}_{2} \mathrm{O}_{5} / \mathrm{NO}_{2}}$ refers to the equilibrium isotope fractionation factor between $\mathrm{N}_{2} \mathrm{O}_{5}$ and $\mathrm{NO}_{2}$, which is a temperaturedependent function (see eq 10 and Table 1 ).

The range of $\gamma$ can be determined by the oxygen isotopic fractionation of $\mathrm{NO}_{3}{ }^{-}$. The $\mathrm{O}$ fractionation can be expressed as

$$
\begin{aligned}
{\left[\delta^{18}{\mathrm{O}-\mathrm{NO}_{3}}^{-}\right] } & =\gamma \times\left[\delta^{18} \mathrm{O}-\mathrm{NO}_{3}^{-}\right]_{\mathrm{OH}}+(1-\gamma) \times\left[\delta^{18} \mathrm{O}-\mathrm{NO}_{3}{ }^{-}\right]_{\mathrm{H}_{2} \mathrm{O}} \\
& =\gamma \times\left[\delta^{18} \mathrm{O}-\mathrm{HNO}_{3}\right]_{\mathrm{OH}}+(1-\gamma) \times\left[\delta^{18} \mathrm{O}-\mathrm{HNO}_{3}\right]_{\mathrm{H}_{2} \mathrm{O}}
\end{aligned}
$$

where $\left[\delta^{18} \mathrm{O}-\mathrm{NO}_{3}{ }^{-}\right]_{\mathrm{OH}}$ and $\left[\delta^{18} \mathrm{O}-\mathrm{NO}_{3}{ }^{-}\right]_{\mathrm{H}_{2} \mathrm{O}}$ are the oxygen isotopic fractionation through the reaction of $\mathrm{NO}_{2}$ and $\cdot \mathrm{OH}$, respectively, and the hydrolysis of $\mathrm{N}_{2} \mathrm{O}_{5}$ on a wetted surface forms $\mathrm{HNO}_{3}$. The $\left[\delta^{18} \mathrm{O}-\mathrm{NO}_{3}{ }^{-}\right]_{\mathrm{OH}}$ can be further expressed as

$$
\begin{aligned}
{\left[\delta^{18} \mathrm{O}-\mathrm{HNO}_{3}\right]_{\mathrm{OH}}=} & \frac{2}{3}\left[\left(\delta^{18} \mathrm{O}-\mathrm{NO}_{2}\right)\right]_{\mathrm{OH}}+\frac{1}{3}\left[\delta^{18} \mathrm{O}-\mathrm{OH}\right]_{\mathrm{OH}} \\
= & \frac{2}{3}\left[\frac{1000 \times\left({ }^{18} \alpha_{\mathrm{NO}_{2} / \mathrm{NO}}-1\right)\left(1-f_{\mathrm{NO}_{2}}\right)}{\left(1-f_{\mathrm{NO}_{2}}\right)+\left({ }^{18} \alpha_{\mathrm{NO}_{2} / \mathrm{NO}} \times f_{\mathrm{NO}_{2}}\right)}\right. \\
& \left.+\left[\delta^{18} \mathrm{~N}-\mathrm{NO}_{x}\right]\right]+\frac{1}{3}\left[\left(\delta^{18} \mathrm{O}-\mathrm{H}_{2} \mathrm{O}\right)\right. \\
& \left.+1000 \times\left({ }^{18} \alpha_{\mathrm{OH} / \mathrm{H}_{2} \mathrm{O}}-1\right)\right]
\end{aligned}
$$

and $\left[\delta^{18} \mathrm{O}-\mathrm{NO}_{3}{ }^{-}\right]_{\mathrm{H}_{2} \mathrm{O}}$ can be determined as follows:

$$
\left[\delta^{18} \mathrm{O}-\mathrm{HNO}_{3}\right]_{\mathrm{H}_{2} \mathrm{O}}=\frac{5}{6}\left(\delta^{18} \mathrm{O}-\mathrm{N}_{2} \mathrm{O}_{5}\right)+\frac{1}{6}\left(\delta^{18} \mathrm{O}-\mathrm{H}_{2} \mathrm{O}\right)
$$


Table 1. Test Constants of $A, B, C$, and $D$ over the Settled Temperature Range of $150-450 \mathrm{~K}$

\begin{tabular}{lccrrc}
\multicolumn{1}{c}{${ }^{m} \alpha_{X / Y}$} & $A$ & $B$ & $C$ & $D$ & \multicolumn{2}{c}{ equation } \\
${ }^{15} \mathrm{NO}_{2} / \mathrm{NO}$ & 3.8834 & -7.7299 & 6.0101 & -0.17928 & 5 \\
${ }^{15} \mathrm{~N}_{2} \mathrm{O}_{5} / \mathrm{NO}_{2}$ & 0.69398 & -1.9859 & 2.3876 & 0.16308 & 6 \\
${ }^{18} \mathrm{NO} / \mathrm{NO}_{2}$ & -0.04129 & 1.1605 & -1.8829 & 0.74723 & 8 \\
${ }^{18} \mathrm{H}_{2} \mathrm{O} / \mathrm{OH}$ & 2.1137 & -3.8026 & 2.5653 & 0.59410 & 8 \\
\hline
\end{tabular}

where ${ }^{18} \alpha_{\mathrm{NO}_{2} / \mathrm{NO}}$ and ${ }^{18} \alpha_{\mathrm{OH} / \mathrm{H}_{2} \mathrm{O}}$ are the equilibrium isotope fractionation factors between $\mathrm{NO}_{2}$ and $\mathrm{NO}$ and $\cdot \mathrm{OH}$ and $\mathrm{H}_{2} \mathrm{O}$, respectively, which are temperature-dependent functions as mentioned above. $\delta^{18} \mathrm{O}-\mathrm{X}$ is the oxygen isotopic composition of $\mathrm{X}$. The range of $\delta^{18} \mathrm{O}-\mathrm{H}_{2} \mathrm{O}$ can be approximated using an estimated tropospheric water vapor $\delta^{18} \mathrm{O}$ range of $-25 \%$ to $0 \%$, and the $\delta^{18} \mathrm{O}$ of $\mathrm{NO}_{2}$ and $\mathrm{N}_{2} \mathrm{O}_{5}$ ranges from $90 \%$ o to $122 \%$ o. $^{10,24}$

In the ${ }^{15} \alpha_{\mathrm{NO}_{2} / \mathrm{NO}}$ and ${ }^{15} \alpha_{\mathrm{N}_{2} \mathrm{O}_{5} / \mathrm{NO}_{2}}$ and ${ }^{18} \alpha_{\mathrm{NO}_{2} / \mathrm{NO}}$ and ${ }^{18} \alpha_{\mathrm{OH} / \mathrm{H}_{2} \mathrm{O}}$ in these equations, the ${ }^{m} \alpha_{X / Y}$ is a function of temperature and can be expressed as

$$
\begin{aligned}
& 1000\left({ }^{m} \alpha_{X / Y}-1\right)=\frac{A}{T^{4}} \times 10^{10}+\frac{B}{T^{3}} \times 10^{8} \\
& +\frac{C}{T^{2}} \times 10^{6}+\frac{D}{T} \times 10^{4}
\end{aligned}
$$

where $A, B, C$, and $D$ are experimental constants (Table 1 ) over the temperature range of $150-450 \mathrm{~K}$. For detailed information on the fractionation (eqs 4-10 and Table 1), readers can refer to Walters et al. ${ }^{10,23,25}$

On the basis of eqs 7-10 and the measured $\delta^{18} \mathrm{O}-\mathrm{NO}_{3}{ }^{-}$of $\mathrm{PM}_{2.5}$ on $\mathrm{BH}$ Island, a Monte Carlo simulation was performed to generate 10000 feasible solutions, which determined that the error between predicted and measured $\delta^{18} \mathrm{O}$ was less than $0.5 \%$. Consequently, the range and median of the contribution ratio $(\gamma)$ are shown in Figure S5. The maximum and minimum $\gamma$ were then input into eq 4 and linked with eqs 5 and 6 to generate the range of nitrogen isotopic fractionation. The maximum and minimum of the nitrogen isotopic fractionation were averaged as mean values, and half of their difference divided by 1.96 was used as the standard deviation.

In principle, the $\delta^{15} \mathrm{~N}-\mathrm{NO}_{x}$ values in the atmosphere are unknown. However, it is expected that the values of $\delta^{15} \mathrm{~N}-\mathrm{NO}_{x}$ in the atmosphere should range between the original values emitted from sources and the values reached under equilibrium fractionation conditions. In this study, coal combustion $(13.72 \% 0 \pm 4.57 \% 0)$, mobile sources $(-3.71 \%$ $\pm 10.40 \%$ ) biomass burning $(1.04 \% 0 \pm 4.13 \% 0)$, and biogenic soil emissions $(-33.77 \% 0 \pm 12.16 \%$ o $)$ were considered to be the dominant contributors of $\mathrm{NO}_{x}$ (Text S3). To determine the $\delta^{15} \mathrm{~N}-\mathrm{NO}_{x}$ in the atmosphere, an iterative model was performed with a simulation step of 0.01 times the equilibrium fractionation value based on the $\delta^{15} \mathrm{~N}-\mathrm{NO}_{x}$ values of the emission sources (mean and standard deviation) and the measured $\delta^{15} \mathrm{~N}_{-} \mathrm{NO}_{3}{ }^{-}$in $\mathrm{PM}_{2.5}$ on $\mathrm{BH}$ Island. We found that the model results with 0.52 times the equilibrium fractionation value had the highest probability distribution of all source contributions and were considered to be the final solution in this study.

\section{RESULTS AND DISCUSSION}

Concentration Regime and Factors Affecting the Conversion of $\mathrm{NO}_{x}$. Figure $\mathrm{S} 6$ shows the $\mathrm{PM}_{2.5}$ and $\mathrm{p}-\mathrm{NO}_{3}{ }^{-}$ concentrations and the corresponding meteorological parameters between August 2014 and September 2015 on BH Island. It can be seen that the $\mathrm{PM}_{2.5}$ concentrations were distributed over a wide range from 5.39 to $267.11 \mu \mathrm{g} \mathrm{m}^{-3}$, with a mean of $63.10 \pm$ $39.01 \mu \mathrm{g} \mathrm{m}^{-3}$, which was slightly higher than that at Tuoji Island $\left(53.22 \mu \mathrm{g} \mathrm{m}^{-3}\right),{ }^{26}$ a national atmospheric background monitoring station (Figure S3). A similar phenomenon was observed for $\mathrm{NO}_{3}{ }^{-}$(range $=0.64$ to $35.21 \mu \mathrm{g} \mathrm{m}^{-3}$, mean $=6.45 \pm 4.92 \mu \mathrm{g}$ $\mathrm{m}^{-3}$ ). The corresponding ambient temperature, $\mathrm{RH}$, and WS had an insignificant correlation with the one-year data set of $\mathrm{NO}_{3}{ }^{-}$ concentrations, suggesting a weak impact of these meteorological parameters on the variation of the $\mathrm{NO}_{3}{ }^{-}$concentration (Text S4). However, the $\mathrm{NO}_{3}^{-}$concentrations were positively correlated with ambient temperature and $\mathrm{RH}$ for two adjacent samples, with $r$ of $0.67(p<0.01)$ and $0.47(p<0.02)$, respectively. This indicated that the high frequency in the variation of ambient temperature and $\mathrm{RH}$ may promote the generation of $\mathrm{NO}_{3}{ }^{-}$, and the impact of ambient temperature was stronger than that of the other meteorological parameters.

A distinct seasonal variation of $\mathrm{PM}_{2.5}$ concentration was found, with the highest value $\left(72.45 \pm 45.70 \mu \mathrm{g} \mathrm{m}^{-3}\right)$ in winter and lowest value $\left(45.84 \pm 28.87 \mu \mathrm{g} \mathrm{m}^{-3}\right)$ in summer. The $\mathrm{NO}_{3}{ }^{-}$ concentrations were $6.34 \pm 3.41,5.78 \pm 4.05,6.92 \pm 6.77$, and $6.09 \pm 4.43 \mu \mathrm{g} \mathrm{m}^{-3}$ in fall, winter, spring, and summer, respectively, indicating an insignificant difference among the seasons. This tendency for a difference in $\mathrm{PM}_{2.5}$ and $\mathrm{NO}_{3}{ }^{-}$could be attributed to their formation processes. In winter, the relatively stable atmosphere results in the accumulation of particles. $^{27}$ In contrast, the ambient temperature and $\mathrm{RH}$ influence the $\mathrm{NO}_{3}{ }^{-}$concentration, with the oxidation rate of $\mathrm{NO}_{x}$ to $\mathrm{NO}_{3}{ }^{-}$usually being lower during cool periods although there is higher concentration of $\mathrm{NO}_{x}$ at that time (Figure S8). ${ }^{28}$ In summer, $\mathrm{NO}_{x}$ is present at low concentration, while the higher oxidation rate (dominat oxidant: $\cdot \mathrm{OH}$ ) of $\mathrm{NO}_{x}$ to $\mathrm{NO}_{3}{ }^{-}$results in an increase in the $\mathrm{NO}_{3}{ }^{-}$concentration (Text S5). The difference in formation processes was verified by the seasonal ratio of $\mathrm{NO}_{3}^{-} / \mathrm{PM}_{2.5}$ (reference of $\mathrm{NO}_{x}$ oxidation rate) in this study. The annual average value of the $\mathrm{NO}_{3}{ }^{-} / \mathrm{PM}_{2.5}$ ratio was $0.11 \pm 0.07$, and the highest $(0.15 \pm 0.07)$ and lowest $(0.08 \pm$ 0.02 ) values were found in summer and winter, respectively.

Sources and Conversion of $\mathrm{NO}_{x}$ Based on $\mathrm{N}$ and $\mathrm{O}$ Isotopic Features. During the sampling period, the $\delta^{15} \mathrm{~N}^{-\mathrm{NO}_{3}}{ }^{-}$ value varied between $-1.7 \%$ and $+24.0 \%$ (Figure S9), with an annual mean value of $8.2 \pm 6.2 \%$. The one-year $\delta^{15} \mathrm{~N}_{-} \mathrm{NO}_{3}{ }^{-}$ value was strongly correlated with the ambient temperature $(r=$ $-0.80, p<0.01$ ), although it had an insignificant relationship with the $\mathrm{NO}_{3}{ }^{-}$concentration and other meteorological parameters. The negative correlation was in agreement with the high $\delta^{15} \mathrm{~N}_{-} \mathrm{NO}_{3}^{-}$value observed in the cool season, characterized by a low ambient temperature. In the warm season, the opposite relationship was apparent. A similar result was reported in a previous study of the $\mathrm{NO}_{3}{ }^{-}$in precipitation in Guangzhou, China. ${ }^{24}$

In the atmosphere, the oxygen atoms of $\mathrm{NO}_{x}$ are rapidly exchanged with $\mathrm{O}_{3}$ in the $\mathrm{NO} / \mathrm{NO}_{2}$ cycle (see eqs $\mathrm{R} 1-\mathrm{R} 3$ ), and the $\delta^{18} \mathrm{O}-\mathrm{NO}_{3}{ }^{-}$value is determined by its generation pathways (R4-R7), rather than the original $\mathrm{NO}_{x}$ sources. ${ }^{11}$ Thus, $\delta^{18} \mathrm{O}$ $\mathrm{NO}_{3}{ }^{-}$can be used to determine the conversion of $\mathrm{NO}_{x}$ to $\mathrm{NO}_{3}{ }^{-}$ 


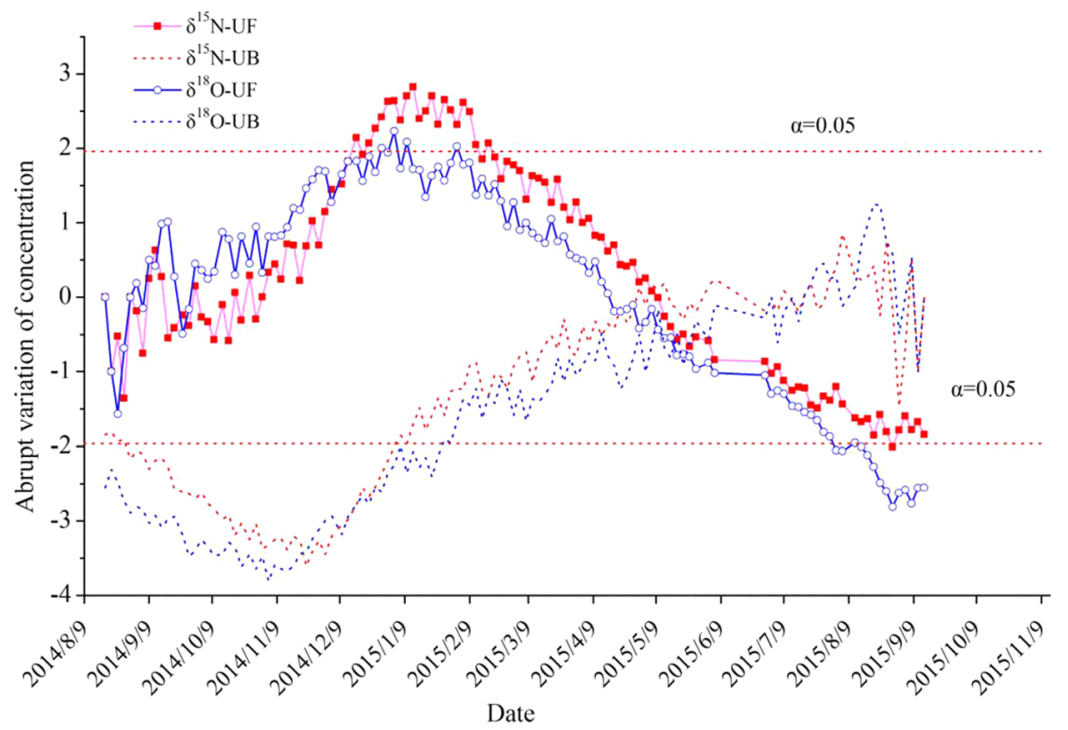

Figure 2. Abrupt variations of $\delta^{15} \mathrm{~N}$ and $\delta^{18} \mathrm{O}$ values by the $\mathrm{M}-\mathrm{K}$ test on $\mathrm{BH}$ Island. Two red dotted lines show the range of significant level at $95 \%$.

in the atmosphere. ${ }^{24}$ In this study, the $\delta^{18} \mathrm{O}-\mathrm{NO}_{3}{ }^{-}$value was well within the broad range of values in previous reports, ${ }^{12,24,29}$ ranging from $49.4 \%$ to $103.9 \%$ (Figure S9). In the Bayesian mixing model, it was assumed that two-thirds of the oxygen atoms in $\mathrm{NO}_{3}{ }^{-}$were derived from $\mathrm{O}_{3}$ and one-third from $\cdot \mathrm{OH}$ in the $\cdot \mathrm{OH}$ generation pathway (R4); correspondingly, five-sixths of the oxygen atoms were derived from $\mathrm{O}_{3}$ and one-sixth from . $\mathrm{OH}$ in the $\mathrm{O}_{3}$ pathway (R5-R7). The ranges of $\delta^{18} \mathrm{O}-\mathrm{O}_{3}$ and $\delta^{18} \mathrm{O}-\mathrm{H}_{2} \mathrm{O}$ values were $90 \%$ to $122 \%$ and $-25 \%$ o to $0 \%$, respectively. The respective contributions of the two generation pathways were assessed by a Monte Carlo simulation, and the range and median of the contribution for the $\mathrm{OH}$ generation pathway are shown in Figure S5, as mentioned above. The range was wide due to the broad range of $\delta^{18} \mathrm{O}-\mathrm{O}_{3}$ and $\delta^{18} \mathrm{O}-\mathrm{H}_{2} \mathrm{O}$ values used; however, the median had a clear seasonal trend. Specifically, the proportional contributions were $0.35 \pm 0.16$, $0.24 \pm 0.16,0.47 \pm 0.17$, and $0.68 \pm 0.10$ in fall, winter, spring, and summer, respectively. This implied the dominance of the $\mathrm{OH}$ generation pathway in summer and the $\mathrm{O}_{3}$ generation pathway during winter. This finding was consistent with the average value of $\delta^{18} \mathrm{O}-\mathrm{NO}_{3}{ }^{-}$being $88.1 \pm 10.2 \%$ in winter, which was significantly higher than in summer $(65.0 \pm 5.8 \%$ o). The seasonal variation of $\delta^{18} \mathrm{O}$ indicated that the main oxidation agent for $\mathrm{NO}_{x}$ on $\mathrm{BH}$ Island could change from $\mathrm{O}_{3}$ in cold times of the year to $\cdot \mathrm{OH}$ in warm ones. ${ }^{30}$

For further identification of the temporal trends and significant changes of $\delta^{15} \mathrm{~N}_{-} \mathrm{NO}_{3}{ }^{-}$and $\delta^{18} \mathrm{O}-\mathrm{NO}_{3}{ }^{-}$values, a sequential Mann-Kendall test (M-K, Text S6) was performed. Figure 2 shows the sequential M-K result for $\delta^{15} \mathrm{~N}_{-} \mathrm{NO}_{3}{ }^{-}$and $\delta^{18} \mathrm{O}-\mathrm{NO}_{3}{ }^{-}$ values, in which both the statistics for the forward series, UF, and backward series, UB, are plotted against time. The point of intersection for UF and UB represents the starting point of the abrupt change in the time series data. The abrupt change for $\delta^{15} \mathrm{~N}$ and $\delta^{18} \mathrm{O}$ began at the end of April and early May, respectively, with both having similar temporal trends. For $\delta^{18} \mathrm{O}_{-\mathrm{NO}_{3}}^{-}, 34.2 \%$ $\pm 17.7 \%$ and $65.2 \% \pm 10.9 \%$ of $\mathrm{NO}_{3}{ }^{-}$was generated by the $\cdot \mathrm{OH}$ pathway before and after the point of abrupt change. The time of this change was also exactly in agreement with the change from cold to warm weather on $\mathrm{BH}$ Island (Figure S10). However, the decline in the temporal trend of $\delta^{15} \mathrm{~N}^{-\mathrm{NO}_{3}}{ }^{-}$was very complicated and contained a signal of source variation.
Generally, $\mathrm{NO}_{3}{ }^{-}$in the atmosphere is derived from the oxidization of $\mathrm{NO}_{x}$, for which $\delta^{15} \mathrm{~N}-\mathrm{NO}_{x}$ values from different anthropogenic combustion and biogenic generation processes are reported to differ. ${ }^{31,32}$ For example, $\mathrm{NO}_{x}$ from coal combustion usually has a higher $\delta^{15} \mathrm{~N}$ value, ${ }^{33}$ while the $\delta^{15} \mathrm{~N}$ value from mobile sources or biogenic soil emissions is often negative. ${ }^{32,34}$ Although there is isotopic fractionation of $\delta^{15} \mathrm{~N}$ during the conversion of $\mathrm{NO}_{x}$ to $\mathrm{NO}_{3}{ }^{-25}$ many studies have suggested that the sources of $\mathrm{NO}_{x}$ can be traced using the $\delta^{15} \mathrm{~N}$ $\mathrm{NO}_{3}{ }^{-}$values. ${ }^{11,35}$ Thus, the observed declining trend of $\delta^{15} \mathrm{~N}$ $\mathrm{NO}_{3}{ }^{-}$values can be interpreted as a consequence of a change in the $\mathrm{NO}_{x}$ source. This change could be partly attributed to the reduction of emissions from coal combustion due to the less frequent use of central heating in North China as the ambient temperature increased ${ }^{36}$ and was partly ascribed to the increase of biogenic soil emissions under the same conditions.

Tentative Exploration of $\mathrm{NO}_{x}$ Sources Based on a Chemical Analysis. Various "trace species" in aerosols can supply crucial source information. In this study, we turned to the relationships between $\mathrm{NO}_{3}{ }^{-}$and these species as an independent means of identifying the sources of $\mathrm{NO}_{x}$. The correlation coefficients between daily $\mathrm{NO}_{3}{ }^{-}$and trace species $\left(\mathrm{SO}_{4}{ }^{2-}, \mathrm{NH}_{4}{ }^{+}\right.$, $\mathrm{K}^{+}, \mathrm{EC}, \mathrm{Ca}^{2+}, \mathrm{Cl}^{-}, \mathrm{Na}^{+}$, and $\mathrm{Mg}^{2+}$ ) in different seasons were obtained, as displayed in Figure 3. Some typical combustion signals $\left(\mathrm{EC}, \mathrm{K}^{+}\right.$, and $\left.\mathrm{SO}_{4}{ }^{2-}\right)$ were strongly correlated with $\mathrm{NO}_{3}{ }^{-}$ throughout the whole year, suggesting that $\mathrm{NO}_{3}{ }^{-}$was mainly derived from combustion sources. ${ }^{37} \mathrm{EC}$ is a primary pollutant, which originates exclusively from the incomplete combustion of carbon-containing material, such as fossil fuels and biomass. ${ }^{38}$ The use of $\mathrm{K}^{+}$as a tracer of biomass burning has been established, ${ }^{39}$ while $\mathrm{SO}_{4}{ }^{2-}$ results from the transformation of $\mathrm{SO}_{2}$, which is mostly produced from industrial or domestic coal combustion in China. ${ }^{40}$ There was a relatively strong correlation between $\mathrm{SO}_{4}{ }^{2-}$ and $\mathrm{NO}_{3}{ }^{-}$in winter and spring when large amounts of coal were consumed for heating, further implying that $\mathrm{NO}_{3}{ }^{-}$in the two seasons originated from coal combustion. In addition to the combustion signals, "fuel $\mathrm{NH}_{4}^{+}$" (Text S7) displayed a significant relationship with $\mathrm{NO}_{3}{ }^{-}$, also indicating that it had a combustion source (e.g., vehicle exhaust and power plants). 


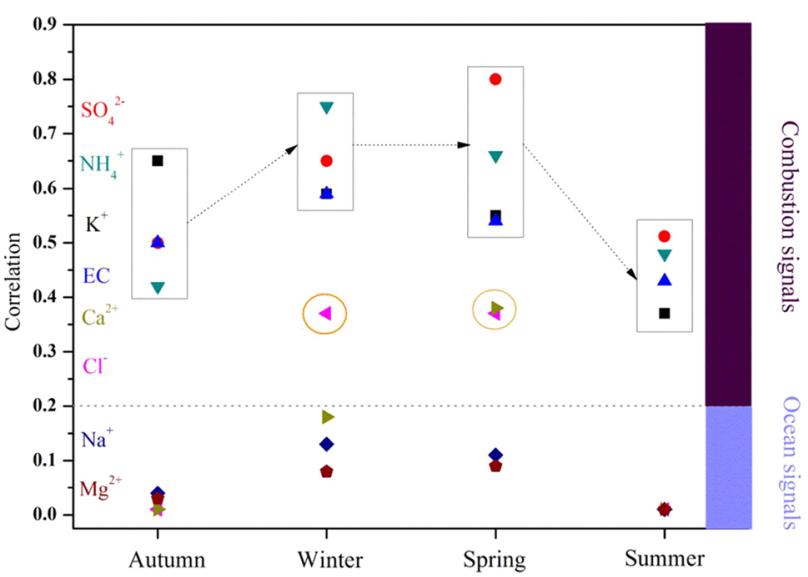

Figure 3. Correlation coefficients between $\mathrm{NO}_{3}{ }^{-}$and trace species in $\mathrm{PM}_{2.5}$ samples on $\mathrm{BH}$.

BH Island is located at the demarcation line between the Bohai Sea and Yellow Sea in the Asian monsoon region, which implies that oceanic or dust sources of $\mathrm{NO}_{3}{ }^{-}$may interfere with the identification of $\mathrm{NO}_{3}{ }^{-}$there. ${ }^{41}$ However, both $\mathrm{Na}^{+}$and $\mathrm{Mg}^{2+}$, as typical ocean signals, were weakly correlated with $\mathrm{NO}_{3}{ }^{-}$. As shown in Figure S11, after removing the ocean contribution (Text S8), the correlations of $\mathrm{SO}_{4}{ }^{2-}, \mathrm{K}^{+}$, and $\mathrm{Cl}^{-}$with $\mathrm{NO}_{3}{ }^{-}$all improved slightly, indicating a slight influence of the ocean on $\mathrm{NO}_{3}{ }^{-}$. There were also weak correlations of $\mathrm{Ca}^{2+}$ and $\mathrm{Cl}^{-}$with $\mathrm{NO}_{3}{ }^{-}$in the warmer period. The relatively strong correlation of $\mathrm{Cl}^{-}$with $\mathrm{NO}_{3}{ }^{-}$in the cold period could be attributed to the large emission of $\mathrm{Cl}^{-}$from coal combustion, ${ }^{42}$ which confirmed the fossil fuel origin of $\mathrm{NO}_{3}{ }^{-}$. In spring, when dust events typically occur, ${ }^{43} \mathrm{Ca}^{2+}$, which is a tracer for dust, had a moderately strong relationship with $\mathrm{NO}_{3}{ }^{-}$. Despite this, dust may not be a source of $\mathrm{NO}_{3}{ }^{-}$(Text S9). Ship emissions, such as those that affect Tuoji Island, ${ }^{44}$ may be a potential source of $\mathrm{NO}_{3}{ }^{-}$. Various studies across the world have highlighted the contribution of ship emissions to atmospheric $\mathrm{NO}_{3}{ }^{-}$, especially in coastal regions. ${ }^{44,45}$ In addition, there is much agricultural land along the coast of the Bohai Sea where the study site was located; thus, biogenic soil emissions due to microbial production may be an important source of $\mathrm{NO}_{3}{ }^{-}$. Biogenic emissions of $\mathrm{NO}_{3}{ }^{-}$have been shown to be strongly regulated by soil moisture and temperature. ${ }^{46}$ This suggests that hot and rainy weather would lead to more intense biogenic soil emissions in summer, which was verified by the lower correlation coefficient between daily $\mathrm{NO}_{3}{ }^{-}$and the typical combustion signals in summer (Figure 3). Combined with the emission inventory of $\mathrm{NO}_{x}$ in North China, combustion sources mainly including mobile sources (vehicle exhaust and ship emissions), coal combustion, biomass burning, and biogenic soil emissions were confirmed as the primary sources of $\mathrm{NO}_{x}$ on $\mathrm{BH}$ Island, providing source infromation for the Bayesian model.

Source Apportionment of $\mathrm{NO}_{x}$ Using a Bayesian Model. In our study, the improved Bayesian model was run for three cases (all year, seasonal, and a moving simulation) to quantify the variable contributions of sources throughout the year. Results based on the year data indicated that $27.78 \% \pm$ $8.89 \%, 36.53 \% \pm 6.66 \%, 22.01 \% \pm 6.92 \%$, and $13.68 \% \pm 3.16 \%$ of $\mathrm{NO}_{x}$ could be attributed to biomass burning, coal combustion, mobile sources, and biogenic soil emissions, respectively. Therefore, coal combustion was the primary source of $\mathrm{NO}_{x}$ on $\mathrm{BH}$ Island, followed by biomass burning and mobile sources, with the latter two sources differing only slightly in magnitude.
This finding differs from previous $\mathrm{NO}_{x}$ emission inventories revealing the absolutely dominant role of coal combustion from power plants. ${ }^{47}$ Although previous studies have shown that power plants are the most important source of $\mathrm{NO}_{x}$ in China, ${ }^{48,49}$ the widespread use of pollution control devices on them has greatly decreased the emission of $\mathrm{NO}_{x}$ under the "Twelfth FiveYear Plan for National Environment Protection" in China. According to the "China Environmental Status Bulletin in 2015", $95 \%$ of all power plants in China had been fitted with $\mathrm{NO}_{x}$ removal systems by 2015 . In Beijing, 25 coal-fired power stations have installed $\mathrm{NO}_{x}$ removal systems, of which 16 and 9 are controlled by a selective catalytic reduction (SCR) system and a combination of SCR with a selective noncatalytic reduction (SNCR) system, respectively. ${ }^{14}$ It was projected that $\mathrm{NO}_{x}$ emissions in 2015 would have decreased by $23.4 \%$ from the baseline projection, with most of the decrease attributed to the reduction of emissions from power plants. ${ }^{50}$ In contrast, the explosive growth in car ownership in recent years has resulted in vehicle exhaust becoming an important source of $\mathrm{NO}_{x}$ pollution. On the basis of car industry surveys, ${ }^{51}$ the growth rate of car ownership in China reached a high of $14 \%$ per year from 2009. The large contribution of vehicle exhaust emissions to $\mathrm{NO}_{x}$ pollution was also in accordance with our previous conclusion regarding the source of $\mathrm{NO}_{3}{ }^{-}$, obtained using the Positive Matrix Factorization (PMF) model. ${ }^{20}$ In addition, ambient air quality, especially for coastal regions, is seriously affected by ship emissions. It was estimated that $8.4 \%$ of $\mathrm{SO}_{2}$ and $11.3 \%$ of the total $\mathrm{NO}_{x}$ emissions in China originated from ships in $2013 .^{52} \mathrm{It}$ has been reported that 0.18 million water transport vessels and 1.07 million fishing boats were active in Chinese waters in 2013, of which one-third were in the Bohai Sea. ${ }^{44}$ Thus, the increasing number of mobile sources observed on $\mathrm{BH}$ Island can also be attributed to ship emissions. The prevalence of large-scale biomass burning and household emissions, ${ }^{53}$ without any pollution control devices, has greatly increased $\mathrm{NO}_{x}$ emissions. One recent study reported that the $\mathrm{NO}_{x}$ emissions from biomass burning increased more than 6-fold from 1990 to 2013 in China. $^{34}$

Figure 4 shows the seasonal contributions (including the range from the first to third quartiles, and the median value) of the four

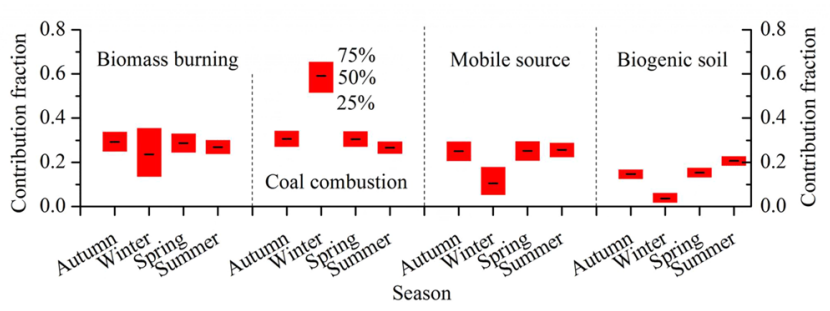

Figure 4. Contributions of coal combustion, mobile source, biomass burning, and biogenic soil emissions for $\mathrm{NO}_{x}$ in different seasons on $\mathrm{BH}$ Island.

sources. In general, the range and median of the four sources were similar in spring and fall. In winter, coal combustion increased significantly (interquartile range of $51.6 \%$ to $65.5 \%$, with a median of $59.1 \%$ ), whereas the importance of the other three sources clearly declined (interquartile range of $13.6 \%$ to $35.5 \%$, with a median of $23.6 \%$ for biomass burning; $5.4 \%$ to $17.9 \%$ with a median of $10.6 \%$ for mobile sources; $1.8 \%$ to $6.1 \%$ with a median of $3.6 \%$ for biogenic source emission). The large contribution of coal combustion in winter was in agreement with 


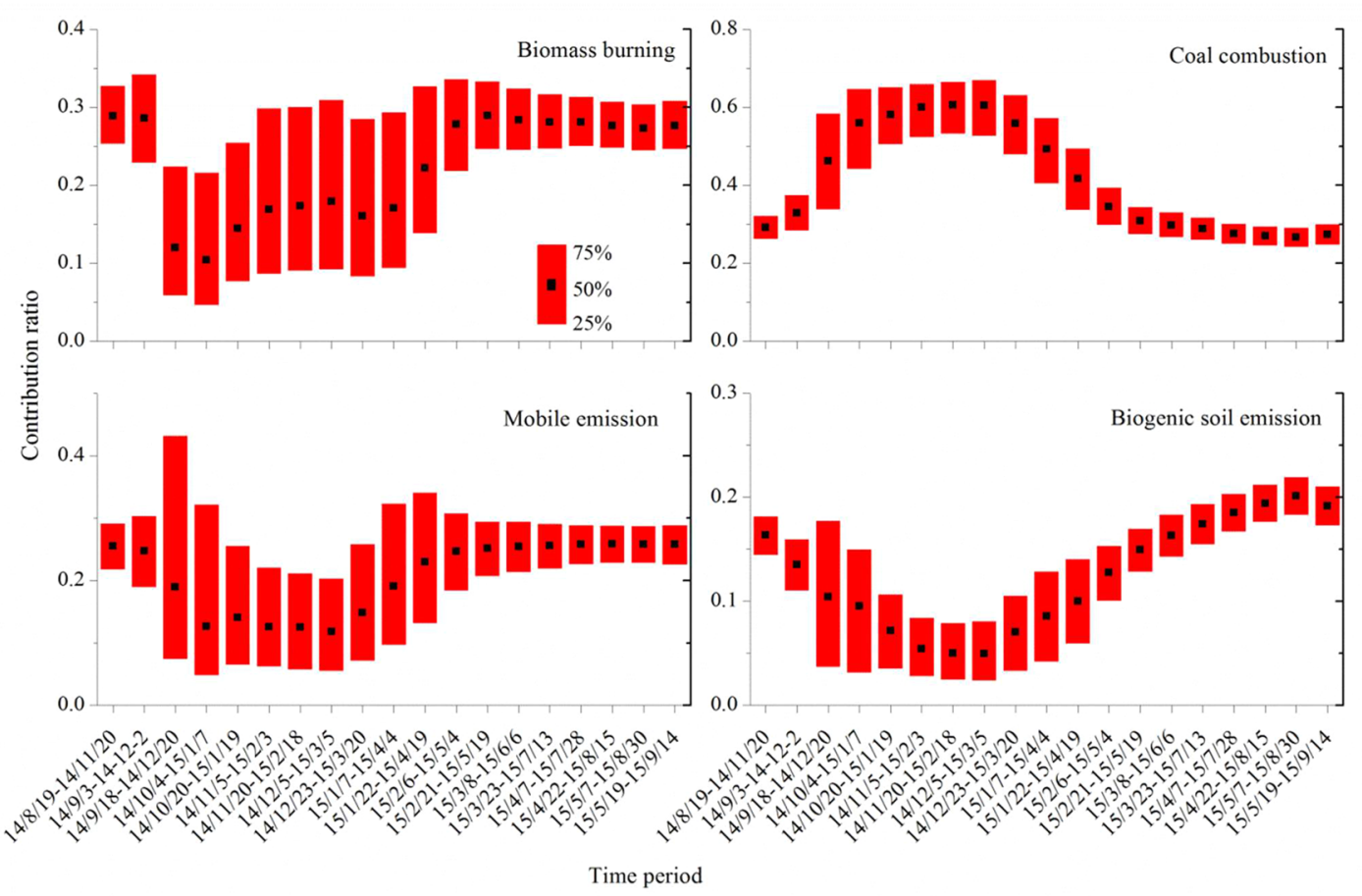

Figure 5. Moving simulations of the respective contributions of coal combustion, mobile source, biomass burning, and biogenic soil emissions during the sampling period.

the aforementioned correlation analysis between $\mathrm{NO}_{3}{ }^{-}$and $\mathrm{SO}_{4}{ }^{2-}$. Biogenic soil emissions declined in winter, but peaked in summer, which was consistent with the corresponding dry and cold and hot and rainy weather, respectively.

To explore further the temporal variation in the contributions of the four sources, the improved Bayesian model was used to produce a moving simulation. This simulation used 30 successive $\delta^{15} \mathrm{~N}_{-\mathrm{NO}_{3}}{ }^{-}$and $\delta^{18} \mathrm{O}-\mathrm{NO}_{3}{ }^{-}$data sets to act as a model run and moved five intervals to execute the next model. Figure 5 displays the time series of the moving contribution of the four sources. Overall, the variation was similar to but more obvious than that of the seasonal simulation. The contribution of coal combustion increased rapidly from 18 September to 20 December, 2014, and correspondingly, the contribution of other sources declined quickly. Then, it peaked in the period from 5 December, 2014, to 5 March, 2015, when large amounts of residential coal were consumed for heating in north China. The ambient temperature, which determines the need for heating, was probably the dominant factor controlling the change of source emissions (Text S10). Therefore, coal combustion for heating was the major contributor to the atmosphere at that time. The observations made in this study were consistent with the conclusion that anthropogenic $\mathrm{NO}_{x}$ in cool months is mainly derived from coal combustion for heating, as reported in a previous study. ${ }^{35}$ According to the emission calculation, the pollution load from 300 million residential coal users with no pollution control equipment would equal that from 20 billion tons of coal used in power utilities. ${ }^{42}$ In China, the residential coal use was estimated to be 6-7 billion tons per year. Thus, domestic coal emissions have gradually attracted more attention in recent years. ${ }^{55}$ On 22 October, 2016, the Ministry of Environmental Protection of the People's Republic of China promulgated the "Technical guide for comprehensive management of civil coal combustion pollution" to control the emissions of domestic coal specifically, which emphasized its significance in air pollution prevention and control planning.

Our study developed a novel $\mathrm{NO}_{x}$ source apportionment method by combining real isotopic data and an improved Bayesian model. The results indicated that coal combustion, mobile sources, and biomass burning were the major contributors of $\mathrm{NO}_{x}$ in North China and should be targeted in plans to reduce $\mathrm{NO}_{x}$ emissions in this area. It is important to note that there was large uncertainty in the evaluation of biomass burning and mobile source contributions, which was partly ascribed to the lack of $\delta^{15} \mathrm{~N}$ values from the different sources in China. Figure S13 displays the probability density distribution of the source emissions used in this study. The distribution of biomass burning and mobile sources had the largest area of overlap, indicating potential misclassification of the two sources. This suggests that there should be more focus on the adequate quantification of nitrogen isotopes for major $\mathrm{NO}_{x}$ sources by undertaking actual measurements. This is crucial for the quantitative source apportionment of $\mathrm{NO}_{x}$ in the atmosphere, especially in China. In addition, the isotopic fractionation from the conversion of $\mathrm{NO}_{x}$ to $\mathrm{NO}_{3}{ }^{-}$was simplified in this study, and it was not possible to incorporate all of the possible equilibrium and kinetic fractionation scenarios. However, this study developed a novel method to apportion $\mathrm{NO}_{x}$ sources that will be useful in further studies.

\section{ASSOCIATED CONTENT}

\section{S Supporting Information}

The Supporting Information is available free of charge on the ACS Publications website at DOI: 10.1021/acs.est.6b06316.

Additional discussion; simplified formation mechanism of $\mathrm{PM}_{2.5}$; statistical $\delta^{15} \mathrm{~N}$ value of $\mathrm{NO}_{x}$; location of sampling site on $\mathrm{BH}$ Island; back trajectory clusters of $\mathrm{BH}$ Island; range and median of contribution ratio for the isotopic 
fractionation; time series of $\mathrm{PM}_{2.5}, \mathrm{NO}_{3}{ }^{-}$concentrations, and meteorological parameters; correlation of temperature and relative humidity between $\mathrm{BH}$ Island and some major cities; monthly concentration of $\mathrm{NO}_{2}$ and $\mathrm{O}_{3}$ in typical cities; variation of $\delta^{15} \mathrm{~N}-\mathrm{NO}_{3}{ }^{-}$and $\delta^{18} \mathrm{O}-\mathrm{NO}_{3}{ }^{-}$in $\mathrm{PM}_{2.5}$ on $\mathrm{BH}$ Island; variation of temperature in the sampling period; correlation coefficient of $\mathrm{NO}_{3}{ }^{-}$and trace species; average temperature, relative humidity, and wind speed during the sampling period; probability density distribution of $\delta^{15}-\mathrm{NO}_{x}$; statistics of $\delta^{15} \mathrm{~N}-\mathrm{NO}_{x}(\mathrm{PDF})$

\section{AUTHOR INFORMATION}

\section{Corresponding Authors}

*Phone: +86-535-2109-160; fax: +86-535-2109-000; e-mail: cgtian@yic.ac.cn (C.T.).

*Phone: +86-024-83970541; fax: +86-024-83970541; e-mail: fangyt@iae.ac.cn (Y.F.).

\section{ORCID}

Chongguo Tian: 0000-0001-6058-9353

Jun Li: 0000-0002-3637-1642

Notes

The authors declare no competing financial interest.

\section{ACKNOWLEDGMENTS}

This work was financially supported by Key Laboratory of Coastal Environmental Processes and Ecological Remediation of the Chinese Academy of Sciences (CAS; Grant No. 2016KFJJ01), the Natural Scientific Foundation of China (NSFC; Grant Nos. 41471413 and 31370464), and the Strategic Priority Research Program of the CAS (Grant Nos. XDA11020402 and XDB05030303). The authors gratefully acknowledge the National Oceanic and Atmospheric Administration's Air Resources Laboratory for providing the HYSPLIT transport model and the READY website (http://www.arl.noaa. gov/ready.html).

\section{REFERENCES}

(1) Andersson, A.; Deng, J.; Du, K.; Zheng, M.; Yan, C.; Skold, M.; Gustafsson, O. Regionally-varying combustion sources of the January 2013 severe haze events over eastern China. Environ. Sci. Technol. 2015, 49 (4), 2038-43.

(2) Chang, Y.; Liu, X.; Deng, C.; Dore, A. J.; Zhuang, G. Source apportionment of atmospheric ammonia before, during, and after the 2014 APEC summit in Beijing using stable nitrogen isotope signatures. Atmos. Chem. Phys. Discuss. 2016, 16 (18), 1-26.

(3) Zhang, Y. L.; Schnelle-Kreis, J.; Abbaszade, G.; Zimmermann, R.; Zotter, P.; Shen, R. R.; Schafer, K.; Shao, L.; Prevot, A. S.; Szidat, S. Source apportionment of elemental carbon in Beijing, China: Insights from radiocarbon and organic marker measurements. Environ. Sci. Technol. 2015, 49 (14), 8408-15.

(4) Liu, J.; Han, Y.; Tang, X.; Zhu, J.; Zhu, T. Estimating adult mortality attributable to $\mathrm{PM}_{2.5}$ exposure in China with assimilated $\mathrm{PM}_{2.5}$ concentrations based on a ground monitoring network. Sci. Total Environ. 2016, 568, 1253-62.

(5) Pan, Y.; Wang, Y.; Zhang, J.; Liu, Z.; Wang, L.; Tian, S.; Tang, G.; Gao, W.; Ji, D.; Song, T.; Wang, Y. Redefining the importance of nitrate during haze pollution to help optimize an emission control strategy. Atmos. Environ. 2016, 141, 197-202.

(6) Wang, G.; Zhang, R.; Gomez, M. E.; Yang, L.; Levy Zamora, M.; Hu, M.; Lin, Y.; Peng, J.; Guo, S.; Meng, J.; Li, J.; Cheng, C.; Hu, T.; Ren, Y.; Wang, Y.; Gao, J.; Cao, J.; An, Z.; Zhou, W.; Li, G.; Wang, J.; Tian, P.; Marrero-Ortiz, W.; Secrest, J.; Du, Z.; Zheng, J.; Shang, D.; Zeng, L.; Shao, M.; Wang, W.; Huang, Y.; Wang, Y.; Zhu, Y.; Li, Y.; Hu, J.; Pan, B.; Cai, L.; Cheng, Y.; Ji, Y.; Zhang, F.; Rosenfeld, D.; Liss, P. S.; Duce, R. A.;
Kolb, C. E.; Molina, M. J. Persistent sulfate formation from London Fog to Chinese haze. Proc. Natl. Acad. Sci. U. S. A. 2016, 113 (48), 1363013635.

(7) Zhao, B.; Wang, S. X.; Liu, H.; Xu, J. Y.; Fu, K.; Klimont, Z.; Hao, J. M.; He, K. B.; Cofala, J.; Amann, M. $\mathrm{NO}_{\mathrm{x}}$ emissions in China: historical trends and future perspectives. Atmos. Chem. Phys. 2013, 13 (19), 98699897.

(8) Han, K. M.; Song, C. H.; Ahn, H. J.; Park, R. S.; Woo, J. H.; Lee, C. K.; Richter, A.; Burrows, J. P.; Kim, J. Y.; Hong, J. H. Investigation of $\mathrm{NO}_{\mathrm{x}}$ emissions and $\mathrm{NO}_{\mathrm{x}}$ - related chemistry in East Asia using CMAQpredicted and GOME-derived $\mathrm{NO}_{2}$ columns. Atmos. Chem. Phys. 2009, 9 (3), 1017-1036.

(9) Shimadera, H.; Kojima, T.; Kondo, A.; Inoue, Y. Performance comparison of CMAQ and CAMx for one-year $\mathrm{PM}_{2.5}$ simulation in Japan. Int. J. Environ. Pollut. 2015, 57 (3-4), 146-161.

(10) Walters, W. W.; Michalski, G. Theoretical calculation of oxygen equilibrium isotope fractionation factors involving various $\mathrm{NO}_{y}$ molecules, $\mathrm{OH}$, and $\mathrm{H}_{2} \mathrm{O}$ and its implications for isotope variations in atmospheric nitrate. Geochim. Cosmochim. Acta 2016, 191, 89-101.

(11) Hastings, M. G.; Sigman, D. M.; Lipschultz, F. Isotopic evidence for source changes of nitrate in rain at Bermuda. J. Geophys. Res. Atmos. 2003, 108 (D24), 4790-4812.

(12) Hastings, M. G.; Steig, E. J.; Sigman, D. M. Seasonal variations in $\mathrm{N}$ and $\mathrm{O}$ isotopes of nitrate in snow at Summit, Greenland: Implications for the study of nitrate in snow and ice cores. J. Geophys. Res. 2004, 109 (D20), 306-317.

(13) Hastings, M. G.; Jarvis, J. C.; Steig, E. J. Anthropogenic impacts on nitrogen isotopes of ice-core nitrate. Science 2009, 324 (5932), 12881288.

(14) Pan, Y.; Tian, S.; Liu, D.; Fang, Y.; Zhu, X.; Zhang, Q.; Zheng, B.; Michalski, G.; Wang, Y. Fossil fuel combustion-related emissions dominate atmospheric ammonia sources during severe haze episodes: Evidence from $\delta^{15} \mathrm{~N}$-stable isotope in size-resolved aerosol ammonium. Environ. Sci. Technol. 2016, 50 (15), 8049-56.

(15) Parnell, A. C.; Phillips, D. L.; Bearhop, S.; Semmens, B. X.; Ward, E. J.; Moore, J. W.; Jackson, A. L.; Grey, J.; Kelly, D. J.; Inger, R. Bayesian stable isotope mixing models. Environmetrics 2013, 24 (6), 387-399.

(16) Zong, Z.; Wang, X.; Tian, C.; Chen, Y.; Han, G.; Li, J.; Zhang, G. Source and formation characteristics of water-soluble organic carbon in the anthropogenic-influenced Yellow River Delta, North China. Atmos. Environ. 2016, 144, 124-132.

(17) Mcllvin, M. R.; Altabet, M. A. Chemical conversion of nitrate and nitrite to nitrous oxide for nitrogen and oxygen isotopic analysis in freshwater and seawater. Anal. Chem. 2005, 77 (17), 5589-5595.

(18) Bohlke, J. K.; Mroczkowski, S. J.; Coplen, T. B. Oxygen isotopes in nitrate: New reference materials for O-18: O-17: O-16 measurements and observations on nitrate-water equilibration. Rapid Commun. Mass Spectrom. 2003, 17 (16), 1835-1846.

(19) Wankel, S. D.; Kendall, C.; Francis, C. A.; Paytan, A. Nitrogen sources and cycling in the San Francisco Bay Estuary: A nitrate dual isotopic composition approach. Limnol. Oceanogr. 2006, 51 (4), 16541664.

(20) Zong, Z.; Wang, X.; Tian, C.; Chen, Y.; Qu, L.; Ji, L.; Zhi, G.; Li, J.; Zhang, G. Source apportionment of $\mathrm{PM}_{2.5}$ at a regional background site in North China using PMF linked with radiocarbon analysis: Insight into the contribution of biomass burning. Atmos. Chem. Phys. 2016, 16 (17), 11249-11265.

(21) Parnell, A. C.; Inger, R.; Bearhop, S.; Jackson, A. L. Source partitioning using stable isotopes: Coping with too much variation. PLoS One 2010, 5 (3), e9672.

(22) Moore, J. W.; Semmens, B. X. Incorporating uncertainty and prior information into stable isotope mixing models. Ecol. Lett. 2008, 11 (5), $470-480$.

(23) Walters, W. W.; Simonini, D. S.; Michalski, G. Nitrogen isotope exchange between $\mathrm{NO}$ and $\mathrm{NO}_{2}$ and its implications for $\delta^{15} \mathrm{~N}$ variations in tropospheric $\mathrm{NO}_{\mathrm{x}}$ and atmospheric nitrate. Geophy. Res. Lett. 2016, 43 (1), 440-448.

(24) Fang, Y. T.; Koba, K.; Wang, X. M.; Wen, D. Z.; Li, J.; Takebayashi, Y.; Liu, X. Y.; Yoh, M. Anthropogenic imprints on nitrogen 
and oxygen isotopic composition of precipitation nitrate in a nitrogenpolluted city in southern China. Atmos. Chem. Phys. 2011, 11 (3), 13131325.

(25) Walters, W. W.; Michalski, G. Theoretical calculation of nitrogen isotope equilibrium exchange fractionation factors for various $\mathrm{NO}_{y}$ molecules. Geochim. Cosmochim. Acta 2015, 164, 284-297.

(26) Wang, X.; Chen, Y.; Tian, C.; Huang, G.; Fang, Y.; Zhang, F.; Zong, Z.; Li, J.; Zhang, G. Impact of agricultural waste burning in the Shandong Peninsula on carbonaceous aerosols in the Bohai Rim, China. Sci. Total Environ. 2014, 481, 311-6.

(27) Feng, Y.; Wen, S.; Chen, Y.; Wang, X.; Lu, H.; Bi, X.; Sheng, G.; $\mathrm{Fu}, \mathrm{J}$. Ambient levels of carbonyl compounds and their sources in Guangzhou, China. Atmos. Environ. 2005, 39 (10), 1789-1800.

(28) Yang, Y. R.; Liu, X. G.; Qu, Y.; An, J. L.; Jiang, R.; Zhang, Y. H.; Sun, Y. L.; Wu, Z.J.; Zhang, F.; Xu, W. Q.; Ma, Q. X. Characteristics and formation mechanism of continuous hazes in China: A case study during the autumn of 2014 in the North China Plain. Atmos. Chem. Phys. 2015, 15 (14), 8165-8178.

(29) Elliott, E. M.; Kendall, C.; Wankel, S. D.; Burns, D. A.; Boyer, E. W.; Harlin, K.; Bain, D. J.; Butler, T. J. Nitrogen isotopes as indicators of $\mathrm{NO}_{\mathrm{x}}$ source contributions to atmospheric nitrate deposition across the Midwestern and northeastern United States. Environ. Sci. Technol. 2007, 41 (22), 7661-7667.

(30) Morin, S.; Savarino, J.; Frey, M. M.; Domine, F.; Jacobi, H. W.; Kaleschke, L.; Martins, J. M. F. Comprehensive isotopic composition of atmospheric nitrate in the Atlantic Ocean boundary layer from 65 degrees S to 79 degrees N. J. Geophys. Res. 2009, 114, D05303.

(31) Fibiger, D. L.; Dibb, J. E.; Chen, D.; Thomas, J. L.; Burkhart, J. F.; Huey, L. G.; Hastings, M. G. Analysis of nitrate in the snow and atmosphere at Summit, Greenland: Chemistry and transport. J. Geophys. Res. Atmos. 2016, 121 (9), 5010-5030.

(32) Walters, W. W.; Goodwin, S. R.; Michalski, G. Nitrogen stable isotope composition $\left(\delta^{15} \mathrm{~N}\right)$ of vehicle-emitted $\mathrm{NO}_{\mathrm{x}}$. Environ. Sci. Technol. 2015, 49 (4), 2278-85.

(33) Felix, J. D.; Elliott, E. M.; Shaw, S. L. Nitrogen isotopic composition of coal-fired power plant $\mathrm{NO}_{\mathrm{x}}$ : influence of emission controls and implications for global emission inventories. Environ. Sci. Technol. 2012, 46 (6), 3528-35.

(34) Felix, J. D.; Elliott, E. M. Isotopic composition of passively collected nitrogen dioxide emissions: Vehicle, soil and livestock source signatures. Atmos. Environ. 2014, 92, 359-366.

(35) Hou, L.; Zheng, Y.; Liu, M.; Li, X.; Lin, X.; Yin, G.; Gao, J.; Deng, F.; Chen, F.; Jiang, X. Anaerobic ammonium oxidation and its contribution to nitrogen removal in China's coastal wetlands. Sci. Rep. 2015, 5, 15621.

(36) Han, B.; Zhang, R.; Yang, W.; Bai, Z.; Ma, Z.; Zhang, W. Heavy haze episodes in Beijing during January 2013: Inorganic ion chemistry and source analysis using highly time-resolved measurements from an urban site. Sci. Total Environ. 2016, 544, 319-29.

(37) Zhang, R.; Jing, J.; Tao, J.; Hsu, S. C.; Wang, G.; Cao, J.; Lee, C. S. L.; Zhu, L.; Chen, Z.; Zhao, Y.; Shen, Z. Chemical characterization and source apportionment of $\mathrm{PM}_{2.5}$ in Beijing: seasonal perspective. Atmos. Chem. Phys. 2013, 13 (14), 7053-7074.

(38) Hu, G.; Zhang, Y.; Sun, J.; Zhang, L.; Shen, X.; Lin, W.; Yang, Y. Variability, formation and acidity of water-soluble ions in $\mathrm{PM}_{2.5}$ in Beijing based on the semi-continuous observations. Atmos. Res. 2014, 145-146, 1-11.

(39) Chen, W.; Yan, L.; Zhao, H. Seasonal variations of atmospheric pollution and air quality in Beijing. Atmosphere 2015, 6 (12), 17531770.

(40) Han, X.; Guo, Q.; Liu, C.; Fu, P.; Strauss, H.; Yang, J.; Hu, J.; Wei, L.; Ren, H.; Peters, M.; Wei, R.; Tian, L. Using stable isotopes to trace sources and formation processes of sulfate aerosols from Beijing, China. Sci. Rep. 2016, 6, 29958.

(41) Mara, P.; Mihalopoulos, N.; Gogou, A.; Daehnke, K.; Schlarbaum, T.; Emeis, K.-C.; Krom, M. Isotopic composition of nitrate in wet and dry atmospheric deposition on Crete in the eastern Mediterranean Sea. Global Biogeochem. Cy. 2009, 23 (4), GB4002.
(42) Chen, Y.; Tian, C.; Feng, Y.; Zhi, G.; Li, J.; Zhang, G. Measurements of emission factors of $\mathrm{PM}_{2.5}, \mathrm{OC}, \mathrm{EC}$, and $\mathrm{BC}$ for household stoves of coal combustion in China. Atmos. Environ. 2015, 109, 190-196.

(43) Huang, K.; Zhuang, G.; Li, J.; Wang, Q.; Sun, Y.; Lin, Y.; Fu, J. S. Mixing of Asian dust with pollution aerosol and the transformation of aerosol components during the dust storm over China in spring 2007. J. Geophys. Res. 2010, 115, D00K13.

(44) Zhang, F.; Chen, Y.; Tian, C.; Wang, X.; Huang, G.; Fang, Y.; Zong, $Z$. Identification and quantification of shipping emissions in Bohai Rim, China. Sci. Total Environ. 2014, 497-498, 570-7.

(45) Agrawal, H.; Eden, R.; Zhang, X.; Fine, P. M.; Katzenstein, A.; Miller, J.W.; Ospital, J.; Teffera, S.; Cocker, D. R., III Primary Particulate matter from ocean-going engines in the southern California air basin. Environ. Sci. Technol. 2009, 43 (14), 5398-5402.

(46) Scholes, M. C.; Martin, R.; Scholes, R. J.; Parsons, D.; Winstead, E. $\mathrm{NO}$ and $\mathrm{N}_{2} \mathrm{O}$ emissions from savanna soils following the first simulated rains of the season. Nutr. Cycling Agroecosyst. 1997, 48 (1-2), 115-122.

(47) Gu, D. S.; Wang, Y. H.; Smeltzer, C.; Liu, Z. Reduction in $\mathrm{NO}_{x}$ emission trends over China: Regional and seasonal variations. Environ. Sci. Technol. 2013, 47 (22), 12912-12919.

(48) Hao, J. M.; Tian, H. Z.; Lu, Y. Q. Emission inventories of $\mathrm{NO}_{x}$ from commercial energy consumption in China, 1995-1998. Environ. Sci. Technol. 2002, 36 (4), 552-560.

(49) Li, Y.; Lau, A. K. H.; Fung, J. C. H.; Zheng, J.; Liu, S. Importance of $\mathrm{NO}_{\mathrm{x}}$ control for peak ozone reduction in the Pearl River Delta region. J. Geophys. Res. Atmos. 2013, 118 (16), 9428-9443.

(50) Zhao, B.; Wang, S.; Wang, J.; Fu, J. S.; Liu, T.; Xu, J.; Fu, X.; Hao, J. Impact of national $\mathrm{NO}_{\mathrm{x}}$ and $\mathrm{SO}_{2}$ control policies on particulate matter pollution in China. Atmos. Environ. 2013, 77, 453-463.

(51) China Statistical Yearbook, Part XVI: transport, post, and telecommunication services; China Statistics Press: Beijing, 2015.

(52) Zhang, F.; Chen, Y.; Tian, C.; Lou, D.; Li, J.; Zhang, G.; Matthias, V. Emission factors for gaseous and particulate pollutants from offshore diesel engine vessels in China. Atmos. Chem. Phys. 2016, 16 (10), 63196334.

(53) Zong, Z.; Chen, Y.; Tian, C.; Fang, Y.; Wang, X.; Huang, G.; Zhang, F.; Li, J.; Zhang, G. Radiocarbon-based impact assessment of open biomass burning on regional carbonaceous aerosols in North China. Sci. Total Environ. 2015, 518-519, 1-7.

(54) Li, J.; Li, Y.; Bo, Y.; Xie, S. High-resolution historical emission inventories of crop residue burning in fields in China for the period 1990-2013. Atmos. Environ. 2016, 138, 152-161.

(55) Wang, Y.; Xu, Y.; Chen, Y.; Tian, C.; Feng, Y.; Chen, T.; Li, J.; Zhang, G. Influence of different types of coals and stoves on the emissions of parent and oxygenated PAHs from residential coal combustion in China. Environ. Pollut. 2016, 212, 1-8. 